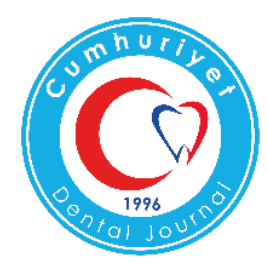

\title{
ULTRASONOGRAPHIC EVALUATION OF MANDIBULAR ELEVATOR MUSCLES TO ASSESS EFFECTS OF ATTRITION-TYPE TOOTH WEAR ON MASTICATORY FUNCTION
}

\author{
Atrizyon Tipi Diş Aşınmasının Çiğneme Fonksiyonu Üzerine Etkisini İncelemek \\ Amacıyla Mandibular Elevator Kasların Ultrasonografik Değerlendirilmesi
}

Gözde ÖZCAN ${ }^{1}$, Duygu GOLLER BULUT ${ }^{2}$, Fatma AVCI ${ }^{3}$

\begin{abstract}
Makale Kodu/Article Code $\quad$ : 428957
Makale Gönderilme Tarihi $\quad$ :05.06.2018

Kabul Tarihi

$: 02.10 .2018$
\end{abstract}

\begin{abstract}
Objectives: Occlusal alterations may result in changes in the functional performance of masticatory muscles. This study was planned to evaluate mandibular elevator muscles of patients with dental attrition by using ultrasonography (USG).
\end{abstract}

Materials and Methods: 30 physiologically dental attrition subjects, aged 35-65 years, were clinically examined by tooth wear index (TWI). Patient group (TWI scores of 2-4) and age-matched controls (TWI scores of 0-1) underwent ultrasonographic analysis to assess the thickness of anterior temporalis, superficial masseter muscles, bilaterally, during clench and rest positions.

Results: The mean thickness of masseter and temporal muscles for rest and clench positions and the ratio between thickness of clench and rest position $(\mathrm{C} / \mathrm{R})$ were evaluated. Muscle thickness had a higher mean value in the tooth wear group. However, the only significant differences were in the $\mathrm{C} / \mathrm{R}$ ratio for left side of masseter $(p=0.04)$ and temporal muscles ( $p=0.03$ ). Although, there was a negative correlation between TWI scores and the muscle C/R ratio for the tooth wear group. A significant positive correlation was found between age and TWI in both groups.

Conclusion: The contraction capacity of the chewing muscles and the attrition mutually interact. This study showed an associate on between the severity of occlusal tooth wear and the $\mathrm{C} / \mathrm{R}$ of chewing muscles. Although dental attrition can occur due to increased jaw muscle activation, and it can also cause a reduction in the contraction capacity of mandibular elevator muscles.

Keywords: Attrition, masticatory muscle, masseter muscle, ultrasonography.
ÖZ

Amaçlar: Okluzal değişiklikler çiğneme kaslarının fonksiyonel performansında değişikliklere neden olabilir. Bu çalışma ultrasonografi (USG) ile dental atrizyonu olan hastaların mandibular elevator kaslarını değerlendirmek amacıyla planlanmıştır.

Gereç ve Yöntemler: 35-65 yaşları arasında 30 adet fizyolojik atrizyonu olan hasta, diş aşınma indeksi (TWI) kullanılarak klinik olarak incelendi. Hasta grubu (2-4 TWI skorları) ve yaş eşleştirilmiş kontroller (0-1 TWI skorları), anterior temporal ve yüzeysel masseter kaslarının, bilateral olarak, diş sıkma ve dinlenme pozisyonları sırasında kalınlığını değerlendirmek amacıyla ultrasonografik analizi yapıldı.

Bulgular: Dinlenme ve diş sıkma pozisyonları için masseter ve temporal kasların ortalama kalınlığı ve diş sıkma ile dinlenme pozisyonu (C / R) arasındaki oran değerlendirildi. Kas kalınlığı, atrizyon grubunda daha yüksek bir ortalama değere sahipti. Bununla birlikte, tek anlamlı fark masseter kasın sol tarafinda $\mathrm{C} / \mathrm{R}$ oranında $(\mathrm{p}=0,04)$ ve temporal kaslarda $(\mathrm{p}=0,03)$ bulundu. Bununla birlikte, TWI skorları ile atrizyon grubu için kas C / R oranı arasında negatif bir korelasyon vardı. Her iki grupta yaş ve TWI arasında anlamlı pozitif korelasyon bulundu.

Sonuç: Çiğneme kaslarının kasılma kapasitesi ve atrizyon karşılıklı olarak etkileşmektedir. Bu çalışmada, okluzal diş aşınmasının şiddeti ile çiğneme kaslarının C/ R' si arasında ilişki bulunmuştur. Çiğneme kaslarının aktivitesinin artması nedeniyle atrizyon meydana gelebilir ve bu da mandibular elevatör kasların kasılma kapasitesinde azalmaya neden olabilir.

Anahtar Kelimeler: Atrizyon, çiğneme kası, masseter kası, ultrasonografi.

\footnotetext{
${ }^{1}$ Specialist Dentist Department of Oral and Maxillofacial Radiology, Kayseri, Turkey

${ }^{2}$ Bolu Abant İzzet Baysal University, Faculty of Dentistry, Department of Oral and Maxillofacial Radiology, Bolu, Turkey

${ }^{3}$ Erciyes University, Faculty of Dentistry, Department of Oral and Maxillofacial Radiology, Kayseri, Turkey
} 


\section{INTRODUCTION}

The masticatory apparatus is a very complex mechanism comprising the jaw bones, muscles, ligaments and teeth. If any one component in this mechanism should fail, it can cause harmful complications in other components. ${ }^{1}$ Tooth wear is regarded as the loss of dental hard tissue due to chemical and/or mechanical factors without bacterial activity. ${ }^{2}$ It is a multifactorial, complex phenomenon consisting of three basic mechanisms: abrasion, erosion and attrition. Abrasion is the pathological wear of dental structures by extreme mechanical irritation. Erosion involved the loss of tooth surface by way of electrochemical or chemical activity. ${ }^{3}$ Attrition is generally a primary physiological adjustment mechanism of masticatory functions caused by friction between reciprocal tooth surfaces or restorations. Attrition is thought to be irreversible and progressive; and should be anticipated as a part of the natural ageing process. ${ }^{4}$ Nevertheless, attrition remains the most frequent kind of tooth wear. ${ }^{5}$ When attrition sets in, left untreated, it can result in the total breakdown of the masticatory system. ${ }^{6,7}$

Some etiological factors of tooth wear as follows: abnormal occlusal strengths, premature contacts in occlusion, bruxism, excessive loading of the teeth and hyperactivity of the masticatory muscles. Attrition-related tooth wear commonly affects the jaw elevator muscles, reducing the strength of contraction and disturbing their functional efficiency. ${ }^{8}$ Therefore, it is essential to understand the morphological and functional muscle changes in subjects with severe attrition-related tooth wear.

MRI and CT scanning are the most widely used techniques to measure jaw muscle crosssectional thickness and volumes. CT scanning, however, shows only cumulative biological effects, while MRI has only limited use because of its cost and availability. ${ }^{9-11}$ Concerning the structural examination of muscles, ultrasonography (USG) has been shown to be beneficial in the confirmation of structural deviations in muscle tissue, such as hypertrophy, muscular contracture, injury and alterations in superficial soft tissue. ${ }^{12,13}$ The technique is non-invasive, simple, reproducible, low cost, easily accepted by patients and uses non-ionized radiation. ${ }^{14}$ In previous studies performed by using USG, positive correlations were reported between USG thickness values of the masseter muscle and the magnitude of bite force. Therefore, USG is an essential tool for analysing the functional efficiency of jaw elevator muscle contraction during dental clenching by measuring muscle thickness. ${ }^{15}$

To investigate the adaptive changes in the masticatory muscles of cases with attritionrelated tooth wear, a study was planned to determine jaw elevator muscle thickness during clench and rest and to calculate Clench/Rest ratio of the muscles (defined as 'contraction activity') by USG in mature age groups with dental attrition and controls.

\section{MATERIALS AND METHODS}

The data was collected in the Department of Dentomaxillofacial Radiology at the Dentistry Faculty of Erciyes University from patients who applied to the oral diagnosis clinic for routine clinical examination in 2016, while conforming to the criteria of The Helsinki Declaration, ICH Guideline for Good Clinical Practice. Informed consent was obtained from each subject at the initiation of the study prior to confirmation of their suitability for the study. The subjects were free to withdraw from the study at any time and for any reason without prejudice. The protocol was approved by the Local Ethical Committee of the Erciyes University (protocol no 2016/585).

\section{Inclusion and exclusion criteria of the experimental and control groups}

Thirty patients with severe tooth wear and exposed occlusal dentine, 20 women and 10 men (mean age $=46.7 \pm 11$ years), comprised the experimental subject. Two oral radiologists 
(DGB and FA; with 4 years of experience) were made that clinical examination. In an effort to classify the severity of tooth wear, the Tooth Wear Index (TWI) of Smith and Knight was used ${ }^{16}$ :

0 ; No loss of enamel surface characteristics on the buccal, lingual occlusal, incisal and cervical surfaces $(\mathrm{B} / \mathrm{L} / \mathrm{O} / \mathrm{I} / \mathrm{C})$.

1; Loss of enamel surface on the $\mathrm{B} / \mathrm{L} / \mathrm{O} / \mathrm{I}$ and minimal loss of cervical contour

2; Loss of enamel exposing dentin for less than one third of the $\mathrm{B} / \mathrm{L} / \mathrm{O} / \mathrm{I}$, loss of enamel just exposing dentine on the incisal surface and defect less than $1 \mathrm{~mm}$ depth on the cervical surface.

3; Loss of enamel exposing dentine for more than one third of the $\mathrm{B} / \mathrm{L} / \mathrm{O}$, loss of enamel and substantial loss of dentine, but not exposing pulp or secondary dentine on the incisal surface and defect less than 1-2 mm depth on the cervical surface.

4; Complete loss of enamel, pulp exposure and exposure of secondary dentine on the $\mathrm{B} / \mathrm{L} / \mathrm{O}$, pulp exposure or exposure of secondary dentine on the incisal surface, defect more than $2 \mathrm{~mm}$ depth, pulp exposure or exposure of secondary dentine on the cervical surface.

Patients with tooth wear levels TWI 2-4 were included in the (TW) group. Subjects in the study needed to satisfy the following criteria for inclusion:

1. The presence of widespread advanced occlusal surface tooth wear with multiple sites of exposed occlusal dentine and/or pulp (TWI on occlusal/incisal surface 2-4), but normal buccal, lingual and cervical surfaces.

2. The presence of at least one tooth with reciprocally normal occlusion in posterior groups (each premolars and molars region) of both sides (at least 10 teeth/arch in total).

Subjects were excluded from the study on the basis of the following criteria:

1. Patients with parafunctional activities (e.g. bruxism, according to patient anamnesis and clinical examination).

2. Patients with unilateral chewing (patient anamnesis, presence of unilateral painful caries cavitation inhibiting chewing at this side, unilaterally missing posterior teeth).

3. Prior prosthetic treatment in which more than one tooth was restored.

4. Patients presenting with more than one tooth in dire need of repair or with deep caries cavitation.

5. Absence of canine teeth for canineprotected occlusion.

6. Unhealthy adults with chronic medication use that would affect muscular tension, oral micro flora or salivary flow rate.

Age-gender matched controls equalled the number experimental subjects (mean age $=47.7 \pm 10$ years), with the same inclusion and exclusion criteria, although without signs of advanced tooth wear (TWI $0-1$, no wear on buccal, lingual or cervical surfaces). Two groups were similar for dentition status and number of teeth. All subjects underwent clinical examination involving the exploration of occlusal surface integrity and observation of the amount of exposed occlusal surface dentine in order to establish whether they satisfied both the inclusion and exclusion criteria.

\section{Principles of the ultrasonography}

The thicknesses of the masseter (Fig 1) and anterior portion of the temporalis (Fig 2) were assessed bilaterally by ultrasonography (Aplio 500 ToshibaTM, Otawara, Japan; 7-18 MHz linear transducer), and measures were taken directly over the image at the moment of its acquisition, with an approximation of $0.1 \mathrm{~mm}$. The locations analysed by USG were determined by palpation ${ }^{17,18}$, asking the subjects to clench their teeth with maximal effort in accordance with the following orientations: masseter, a level halfway between the zygomatic arch and gonial angle; and anterior portion of the temporalis muscle, in front of the anterior border of the hairline. ${ }^{19}$ 


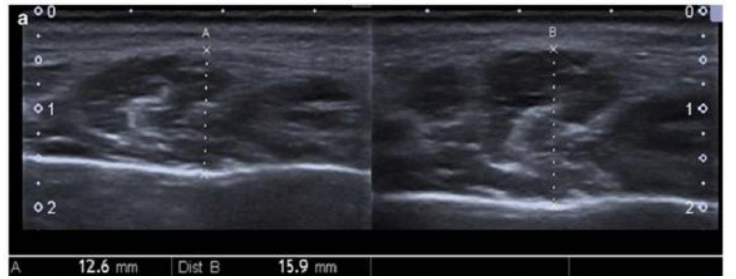

Figure 1. The measurements of masseter muscles during rest and clench.

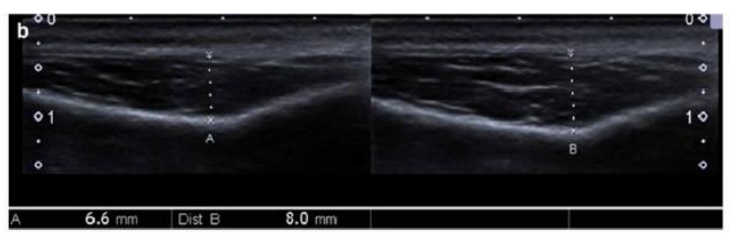

Figure 2. The measurements of temporal muscles during rest and clench.

Throughout the records, the probe was positioned perpendicular to the direction of the muscle fibres. An airtight inert gel was applied on the skin surface and the transducer was moved until optimized images had been obtained. The examination was made with the muscles resting (i.e. relaxed) and in the maximum intercuspal position (i.e. maximum clenching) for both left and right sides. During the examination, the subject remained seated, relaxing against the backrest with their head unrestricted. The muscle thickness was measured from the widest part of the muscles. On the USG image, the distance between the most inner surface and the outermost surface of the muscles was measured. ${ }^{12}$ All the examinations were carried out by the same person (GO; oral radiologist experienced on USG imaging for 2 years). Three acquirements were performed in each muscle situation (relaxed and maximum clenching), with an interval of $2 \mathrm{~min}$ between each acquirement for the subjects to rest their muscles after dental clenching. The thickness of each side was estimated as the mean value of the three repetitions.

\section{Statistical analyses}

Statistical analyses were conducted with SPSS for Windows SPSS ${ }^{\circledR}$ v. 16.0 (IBM Corp., New York, NY; formerly SPSS Inc., Chicago, IL). The measurements were evaluated using the independent and paired samples t-test to compare the means of all values between patients and controls. Values of $p<0.05$ were considered to indicate statistical significance.

\section{RESULTS}

There were 60 subjects enrolled in the study: 30 subjects presenting with severe attritionrelated tooth wear and 30 controls. Groups comprised same number of females $(n=20)$ and males $(n=10)$. Patient and control groups did not differ by age. Table 1 presents the distribution of subjects according to age, gender and TWI scores in both patients with tooth wear and control groups. Among the subjects included in this study, the most frequent tooth wear score was TWI-2 (40\%).

Table 1: The distribution of subjects according to age, gender and TWI scores.

\begin{tabular}{|c|c|c|c|c|c|c|}
\hline \multirow{2}{*}{ subjects } & \multicolumn{3}{|c|}{ Tooth wear } & \multicolumn{3}{|c|}{ Control } \\
\hline & mean age & TWI 2 & TWI3 & mean age & TWIO & TWI 1 \\
\hline Male $(n=10)$ & 45.1 & 8 & 2 & 44.2 & 3 & 7 \\
\hline Female $(n=20)$ & 47.5 & 16 & 4 & 49.4 & 11 & 9 \\
\hline Total & 46.7 & 24 & 6 & 47.7 & 14 & 16 \\
\hline
\end{tabular}

Masseter and temporal muscle thickness during rest and clench positions and the $C / R$ thickness ratio was evaluated. The mean values and standard deviations of these thickness, rates and comparisons of patients and controls are illustrated in Table 2 according to gender. Mean muscle thickness values were higher in the tooth wear group. However, significant differences were only found in $C / R$ ratio for the left side of the masseter $(p=0.04)$ and temporal muscles $(p=0.03)$. Among females, there were significant differences in right masseter muscle thickness during clench and the $\mathrm{C} / \mathrm{R}$ ratio for left masseter muscle. Furthermore, significant differences were found in the $C / R$ ratio for the right side of masseter and left side of the temporal muscles in males. 
Table 2. The mean value of masseter and temporal muscles during rest and clench and clench/rest ratio according to gender with corparisons between groups

\begin{tabular}{|c|c|c|c|c|c|c|c|c|}
\hline \multirow{2}{*}{ muscle } & \multirow[b]{2}{*}{ position } & \multirow[b]{2}{*}{ gender } & \multicolumn{3}{|c|}{ Right } & \multicolumn{3}{|c|}{ Left } \\
\hline & & & Tooth wear & Control & $p$ value & Tooth wear & Control & $p$ value \\
\hline \multirow{9}{*}{ Masseter } & \multirow{3}{*}{ Relax } & Male & $11.06 \pm 0.17$ & $10.11 \pm 1.88$ & 0.13 & $12.24 \pm 1.52$ & $12.85 \pm 0.94$ & 0.29 \\
\hline & & Female & $10.04 \pm 2.27$ & $9.41 \pm 0.96$ & 0.26 & $\mid$\begin{tabular}{|ll}
0 \\
$10.2 \pm 2.4$
\end{tabular} & $10.5 \pm 1.68$ & 0.65 \\
\hline & & Total & $10.38 \pm 1.90$ & $9.64 \pm 1.35$ & 0.91 & $10.88 \pm 2.33$ & $11.2 \pm 1.84$ & 0.46 \\
\hline & \multirow{4}{*}{ Clench } & Male & $13.88 \pm 0.57$ & $14.69 \pm 2.7$ & 0.36 & $\mid$\begin{tabular}{|l|l}
$\mid 15.5 \pm 1.07$ \\
\end{tabular} & $15.86 \pm 1.79$ & 0.59 \\
\hline & & Female & $14.16 \pm 2.42$ & $12.87 \pm 1.21$ & $0.04^{*}$ & $\mid$\begin{tabular}{|ll}
$14.1 \pm 2.32$ \\
\end{tabular} & $13.56 \pm 1.97$ & 0.43 \\
\hline & & Total & $14.07 \pm 1.99$ & $13.48 \pm 2.00$ & 0.25 & $14.56 \pm 2.08$ & $14.32 \pm 2.18$ & 0.66 \\
\hline & & Male & $1.55 \pm 0.04$ & $1.45 \pm 0.07$ & $<0.001^{*}$ & $\mid$\begin{tabular}{|l|l}
$1.27 \pm 0.08$ \\
\end{tabular} & $1.23 \pm 0.06$ & 0.19 \\
\hline & \multirow[t]{2}{*}{ Clench/Relax } & Female & $1.42 \pm 0.14$ & $1.37 \pm 0.1$ & 0.17 & $\mid$\begin{tabular}{|l|}
$1.4 \pm 0.12$ \\
\end{tabular} & $1.29 \pm 0.09$ & $0.004^{*}$ \\
\hline & & Total & $1.47 \pm 0.14$ & $1.40 \pm 0.10$ & 0.38 & $\mid$\begin{tabular}{|l}
$\mid 1.36 \pm 0.12$ \\
$\mid$
\end{tabular} & $1.27 \pm 0.09$ & $0.04^{*}$ \\
\hline \multirow{9}{*}{ Temporal } & \multirow{3}{*}{ Relax } & Male & $7.26 \pm 0.68$ & $7.02 \pm 0.74$ & 0.46 & $7.38 \pm 1.12$ & $7.21 \pm 1.12$ & 0.574 \\
\hline & & Female & $7.15 \pm 1.42$ & $7.12 \pm 0.41$ & 0.92 & $7.91 \pm 1.73$ & $7.78 \pm 0.83$ & 0.76 \\
\hline & & Total & $7.19 \pm 1.21$ & $7.09 \pm 0.53$ & 0.68 & $7.73 \pm 1.56$ & $7.59 \pm 0.96$ & 0.67 \\
\hline & \multirow{4}{*}{ Clench } & Male & $8.2 \pm 0.96$ & $8.16 \pm 0.45$ & 0.9 & $8.3 \pm 1.15$ & $8.74 \pm 1.03$ & 0.38 \\
\hline & & Female & $8.27 \pm 1.72$ & $8.05 \pm 0.44$ & 0.57 & $8.77 \pm 1.97$ & $8.93 \pm 1.4$ & 0.77 \\
\hline & & Total & $8.25 \pm 1.49$ & $8.08 \pm 0.44$ & 0.56 & $8.61 \pm 1.73$ & $8.86 \pm 1.27$ & 0.52 \\
\hline & & Male & $1.22 \pm 0.07$ & $1.16 \pm 0.08$ & 0.26 & $\mid 1.23 \pm 0.11$ & $1.18 \pm 0.06$ & $0.04^{*}$ \\
\hline & \multirow{2}{*}{ Clench/Relax } & Female & $1.25 \pm 0.07$ & $1.13 \pm 0.06$ & 0.27 & $\mid 1.25 \pm 0.09$ & $1.21 \pm 0.07$ & 0.23 \\
\hline & & Total & $1.23 \pm 0.77$ & $1.13 \pm 0.71$ & 0.87 & $\mid$\begin{tabular}{||l}
$\mid 1.24 \pm 0.09$ \\
|
\end{tabular} & $1.19 \pm 0.08$ & $0.03^{*}$ \\
\hline
\end{tabular}

Table 3 illustrates a left-right comparison in patients with tooth wear according to gender. The mean left muscle thickness values in both genders were higher than for the right. Significant differences were found in thickness between rest $(p=0.01)$ and clench positons $(p=0.04)$ for the temporal muscles between both sides. Furthermore, there were significant differences in the thickness of the masseter muscles in males and temporal muscles in females $(p<0.05)$.

Table 3. The mean value of masseter and temporal muscles thickness of tooth-wear group during rest and clench and clench\&rest ratio according to gender with comparisons between sides

\begin{tabular}{|c|c|c|c|c|}
\hline muscles & position & Right & Left & $p$ value \\
\hline \multirow{3}{*}{ Masseter } & Relax & $10.38 \pm 1.90$ & $10.88 \pm 2.33$ & 0.12 \\
\hline & Clench & $14.07 \pm 1.99$ & $14.56 \pm 2.08$ & 0.17 \\
\hline & Clench/Relax & $1.37 \pm 0.14$ & $1.36 \pm 0.12$ & 0.75 \\
\hline \multirow{3}{*}{ Temporal } & Relax & $7.19 \pm 1.21$ & $7.73 \pm 1.56$ & $0.01^{*}$ \\
\hline & Clench & $8.25 \pm 1.49$ & $8.61 \pm 1.73$ & $0.04 *$ \\
\hline & Clench/Relax & $1.14 \pm 0.77$ & $1.11 \pm 0.09$ & 0.25 \\
\hline side & position & Masseter & Temporal & $p$ value \\
\hline Right & Clench/Relax & $1.37 \pm 0.14$ & $1.14 \pm 0.77$ & $<0.001^{*}$ \\
\hline Left & Clench/Relax & $1.36 \pm 0.12$ & $1.11 \pm 0.09$ & $<0.001^{*}$ \\
\hline
\end{tabular}

A gender comparison of mandibular elevator muscles' thickness during rest and clench positions and TWI scores are can be found in Table 4. Statistically significant differences were found in the $\mathrm{C} / \mathrm{R}$ ratio for both left and right sides of the masseter muscles for males and females in the tooth wear group $(p<0.05)$. Although, there were significant differences between the genders in the control group for left and right masseter muscle thickness during clench, there were no such significant differences in the patient group. In addition, there was a significant difference in TWI scores between males and females in the tooth wear group $(p<0.001)$.

Table 4: The p value of masseter and temporal muscles and TWI scores for males and females during relax and clench position and clench/relax ratio and also comparisons between genders.

\begin{tabular}{|c|c|c|c|c|c|c|}
\hline \multirow{3}{*}{ muscles } & \multirow{3}{*}{ positions } & \multirow{3}{*}{ gender } & \multicolumn{2}{|c|}{ Right } & \multicolumn{2}{|c|}{ Left } \\
\hline & & & Tooth wear & Control & Tooth wear & Control \\
\hline & & & $p$ value & $p$ value & $p$ value & $p$ value \\
\hline \multirow{3}{*}{ Masseter } & Relax & $\begin{array}{l}\text { Male } \\
\text { Female }\end{array}$ & 0.17 & 0.18 & 0.02 & $<0.001^{*}$ \\
\hline & Clench & $\begin{array}{l}\text { Male } \\
\text { Female }\end{array}$ & 0.71 & $0.01 *$ & 0.08 & $0.004^{*}$ \\
\hline & $\begin{array}{l}\text { Clench/ } \\
\text { Relax }\end{array}$ & $\begin{array}{l}\text { Male } \\
\text { Female }\end{array}$ & $0.001^{*}$ & 0.05 & $0.006 *$ & 0.06 \\
\hline \multirow{3}{*}{ Temporal } & Relax & $\begin{array}{l}\text { Male } \\
\text { Female }\end{array}$ & 0.82 & 0.62 & 0.38 & 0.12 \\
\hline & Clench & $\begin{array}{l}\text { Male } \\
\text { Female }\end{array}$ & 0.9 & 0.53 & 0.48 & 0.7 \\
\hline & $\begin{array}{l}\text { Clench/ } \\
\text { Relax }\end{array}$ & $\begin{array}{l}\text { Male } \\
\text { Female }\end{array}$ & 0.37 & 0.17 & 0.53 & 0.07 \\
\hline \multirow{3}{*}{\multicolumn{2}{|c|}{$T W I$}} & & Tooth wear & $p$ value & Control & $p$ value \\
\hline & & Male & $2.6 \pm 0.51$ & \multirow{2}{*}{$<0.001 *$} & $0.40 \pm 0.51$ & \multirow{2}{*}{0.31} \\
\hline & & Female & $2 \pm 0$ & & $0.60 \pm 0.5$ & \\
\hline
\end{tabular}

${ }^{*}$ correlation is significant at the 0.01 level (2-tailed)

Table 5 presents the correlation between TWI scores and $\mathrm{C} / \mathrm{R}$ ratios for the mandibular elevator muscles. The negative correlation between $C / R$ ratio of masseter muscles of patients with tooth wear and TWI scores were significant. There was no significant correlation in the control group. Table 5 also illustrates the significant positive correlation between age and TWI in both groups.

Table 5.The correlation values of TWI scores with clench/rest ratio of muscles and age

\begin{tabular}{c|ccc} 
variable & side & \multicolumn{2}{c}{ TWI } \\
& & Tooth wear & Control \\
\hline $\begin{array}{c}\text { Masseter } \\
\text { (C/R) }\end{array}$ & right & $-0.420^{*}$ & -0.023 \\
\hline $\begin{array}{c}\text { Teft } \\
\text { (C/R) }\end{array}$ & right & $-0.425^{*}$ & -0.148 \\
\hline left & -322 & -117 \\
\hline age & & $0.623 *$ & -312 \\
\hline
\end{tabular}

*correlation is significant at the 0.05 level (2-tailed)

\section{DISCUSSION}

Attrition-related tooth wear is a visible sign of physiological functional tooth wear. Such functional tooth wear is usually apparent by means of functional distortion in the masticatory system because increased muscular functioning causes increased tooth wear. ${ }^{1}$ At the same time, progressive tooth wear also changes the occlusion itself, thus affecting muscular 
functions. ${ }^{8} \quad$ Therefore, understanding the functional and morphological changes in the masticatory muscles of patients with attritionrelated tooth wear is important for understanding alterations in the masticatory apparatus of dental attrition cases.

Attrition-related tooth wear occurs as a natural result of the ageing progress. ${ }^{3}$ The present study found a significant positive correlation between TWI scores and age in both experimental and control groups. This result is compatible with the findings of Oginni et $a .^{20}$ and Yadav $^{1}$, Seligman et al. ${ }^{21}$, Egermark-Ericksson ${ }^{22}$, Richmond et al. ${ }^{23}$, but Clark et $a .^{24}$ did not find any relationship between age and degree of attrition. In the present study, it was also found that males had higher attrition scores than females. This result is consistent with those of Oginni et al. ${ }^{20}$

With advanced tooth wear, the number of occlusal contacts has a tendency to occur larger in maximum intercuspation. As tooth wear increases, the occlusal surface of the related tooth can become completely flat. Flat tooth surfaces, therefore, expose a larger area to occlusal contacts. In this position, the mandibular elevator muscles must be capable of generating maximal masticatory strength. According to Oginni et l. $^{20}$, if the tooth wear becomes more severe, the stain and stress on the masticatory muscles and TMJ during chewing increases. In accordance with this, Bakke ${ }^{25}$ reported a significant positive correlation between strength generated during chewing and the number of occlusal contacts. This result supports the outcome of this study that the mean thickness value of muscles during clench is higher in tooth-wear group.

There are studies in the literature showing that USG can be used to determine muscle activity. In the study of Andrade et al. ${ }^{26} \mathrm{EMG}$ activity and muscle thickness with real-time USG of masseter and anterior temporalis muscles in children was recorded. A positive correlation was found between the ultrasonographic thickness of the masseter muscle and the EMG amplitude. Strini et al. ${ }^{27}$ evaluated the maximal bite force, EMG and muscle thickness of the masseter, temporalis and sternocleidomastoid muscles of patients with temporomandibular joint diseases and compared the three methods. The results of three methods were similar to the controls and TMD patients and the authors suggest that USG can also be used to assess muscle activity. Georgiakaki et $a ._{.}{ }^{28}$ found a strong association between the average muscle mass of the masseter muscle and mean EMG activity and stated that USG could be used as a tool for assessing masseter muscle functional capacity through full effort in healthy individuals.

The findings of this study suggest that the thickness of the chewing muscles increases with tooth wear, but contraction activity $(\mathrm{C} / \mathrm{R}$ ratio) is not affected positively due to tooth wear. We found a negative correlation between TWI scores and C/R ratio of masseter muscle. In accordance with the results of the present study, in a study conducted with EMG Sierpinska et $a l^{8}{ }^{8}$ stated that mandibular elevator muscles demonstrate significantly inferior muscular activity at maximal clench in advanced tooth wear patients as compared to healthy controls; although the reasons for this were not clear. They also found a significant negative correlation between elevator muscle activity and TWI.

\section{CONCLUSIONS}

During clinical examination, patients presenting with numerous teeth with advanced tooth wear will likely also have increasingly thick chewing muscles due to the increased contraction necessary to maintain active mastication. On the other hand, the findings of this study show a reduction in the $\mathrm{C} / \mathrm{R}$ ratio of muscles with increased TWI scores. The findings of this study indicate that advanced attrition-related tooth wear in mature adults limits the masticatory functions by not only reducing the edges of teeth, but also decreasing 
the contraction capacity of the chewing muscles. To avoid this, clinicians should endeavour to restore teeth with attrition-related tooth wear before reducing masticatory activity. USG helps to analyse the influence of tooth wear severity on the masticatory apparatus and provides a sophisticated approach to attrition-related tooth wear. This study is important that is the first USG study to focus on dental attrition effects in relation to the mandibular elevator muscles.

\section{Author Disclosure Statement}

None of the authors have any competing financial interests to disclose.

\section{REFERENCES}

1. Yadav S. A Study on Prevalence of Dental Attrition and its Relation to Factors of Age, Gender and to the Signs of TMJ Dysfunction. J Indian Prosthodont Soc. 2011;11(2):98-105.

2. Eccles JD. Tooth surface loss from abrasion, attrition and erosion. Dental Update. 1982;9(7):373-374.

3. Zhang J, Du Y, Wei Z, Tai B, Jiang H, Du

$M$. The prevalence and risk indicators of tooth wear in 12- and 15-year-old adolescents in Central China. BMC Oral Health. 2015 Oct 9;15(1):120.

4. Berry DC, Poole DF. Attrition: possible mechanisms of compensation abstract. J Oral Rehabil. 1976;3(3):201-206.

5. Zum Gahr KH. Classification of wear processes. Microstructure and wear of materials. 1987;10:80-131.

6. Barlett DW. The role of erosion in tooth wear: aetiology, prevention and management. Int Dent J 2005;55(4):277-284.

7. Bartlett DW. Retrospective long term monitoring of tooth wear using study models.

Br Dent J 2003:22;194(4):211-213

8. Sierpinska T, Kuc J, Golebiewska M. Assessment of masticatory muscle activity and occlusion time in patients with advanced tooth wear. Arch Oral Biol. 2015;60(9):1346-1355.

9. Kant P, Bhowate RR, Sharda N. Assessment of cross-sectional thickness and activity of masseter, anterior temporalis and orbicularis oris muscles in oral submucous fibrosis patients and healthy controls: an ultrasonography and electromyography study. Dentomaxillofac Radiol. 2014;43(3):20130016. 10.Hannam AG, Wood WW. Relationships between the size and spatial morphology of humanmasseter and medial pterygoid muscles, the craniofacial skeleton, and jaw mechanics. Am JPhys Anthropol. 1989;80(4):429-445.

11.Newton JP, Abel RW, Robertson EM, Yemm R. Changes in human masseter and medial pterygoid muscles with age: a study by computed tomography. Gerodontics 1987;3(4):151-154.

12.Emshoff R, Bertram S, Strobl $H$. Ultrasonographic cross-sectional characteristics of muscles of the head and neck. Oral Surg Oral Med Oral Pathol Oral Radiol Endod. 1999;87(1):93-106.

13.Barber L, Barret R, Lichtwark G. Validity and reliability of a simple ultrasound approach to measure medial gastrocnemius muscle length. J Anat. 2011;218(6):637-642.

14. Serra MD, Duarte Gavião $M B$, dos Santos Uchôa MN. The use of ultrasound in the investigation of the muscles of mastication. Ultrasound Med Biol. 2008;34(12):1875-1884. 15.Georgiakaki I, Tortopidis D, Garefis P, Kiliaridis S. Ultrasonographic thickness and electromyographic activity of masseter muscle of human females. $\mathbf{J}$ Oral Rehabil. 2007;34(2):121-128.

16. Smith BG, Knight JK. An index for measuring the wear of teeth. $\mathrm{Br}$ Dent $\mathrm{J}$. 1984;156(12):435-438.

17. Castelo PM, Gavião MB, Pereira LJ, Bonjardim LR. Masticatory muscle thickness: bite force, and occlusal contacts in young children with unilateral posterior crossbite. Eur J Orthod. 2007;29(2):149-156.

18.Kiliaridis $S$, Kälebo $P$. Masseter muscle thickness measured by ultrasonography and its relation to facial morphology. J Dent Res. 1991;70(9):1262-1265. 
19.Passier LN, Nasciemento MP, Gesch JM, Haines TP. Physiotherapist observation of head and neck alignment. Physiother Theory Pract. 2010;26(6):416-423.

20.20. Oginni AO, Oginni FO, AdekoyaSofowora CA. Signs and symptoms of temporomandibular disorders in Nigerian adult patients with and without occlusal tooth wear. Community Dent Health. 2007;24(3):156-160. 21. Seligman DA, Pullinger AG, Solberg WK. The prevalence of dental attrition and its association with factors of age, gender, occlusion and TMJ symptomology. J Dent Res. 1988;67(10):1323-1333.

22.Egermark-Ericksson I. Malocclusion and some functional recordings of the masticatory system in Swedish school children. Swed Dent J. 1982;6(1):9-20.

23.Richmond G, Rugh JD, Dolfi R, Wasilewisky JW. Survey of bruxism in an institutionalized mentally retarded population. Am J Ment Defic. 1984;88(4):418-421.

24. Clarke NG, Townsend GC, Carey SE. Bruxing patterns in man during sleep. $\mathrm{J}$ Oral Rehabil. 1984;11(2):123-127.

25.Bakke M, Michler L, Moller E. Occlusal control of mandibular elevator muscle. Scand J Dent Res 1992;100(5):284-291.
26. Andrade AS, Gavião $M B$, Derossi $M$, Gameiro GH. Electromyographic activity and thickness of masticatory muscles in children with unilateral posterior crossbite. Clin Anat. 2009;22(2):200-206.

27. Strini PJ, Strini PJ, Barbosa Tde S, Gavião MB. Assessment of thickness and function of masticatory and cervical muscles in adults with and without temporomandibular disorders. Arch Oral Biol. 2013;58(9):1100-1108.

28.Georgiakaki I, Tortopidis D, Garefis P, et al. Ultrasonographic thickness and electromyographic activity of masseter muscle of human females. $\mathbf{J}$ Oral Rehabil. 2007;34(2):121-128

\section{Corresponding Author}

Duygu GOLLER BULUT

Bolu Abant Izzet Baysal University

Faculty of Dentistry

Department of Oral and Maxillofacial

Radiology

Bolu, Turkey.

Phone : +90 37425410 00/8350

Fax : :903742700066

E-mail : duygugoller@hotmail.com 